\title{
Naïve and memory CD8 T cell pool homeostasis in advanced aging: impact of age and of antigen-specific responses to cytomegalovirus
}

\author{
Rosanna Vescovini • Francesco Fausto Fagnoni - Anna Rita Telera - Laura Bucci • \\ Mario Pedrazzoni - Francesca Magalini • Adriano Stella • Federico Pasin • \\ Maria Cristina Medici • Adriana Calderaro • Riccardo Volpi • Daniela Monti • \\ Claudio Franceschi • Janko Nikolich-Žugich • Paolo Sansoni
}

Received: 21 February 2013 / Accepted: 22 October 2013 / Published online: 8 December 2013

(C) The Author(s) 2013. This article is published with open access at Springerlink.com

\begin{abstract}
Alterations in the circulating CD8+ T cell pool, with a loss of naïve and accumulation of effector/effector memory cells, are pronounced in older adults. However, homeostatic forces that dictate such changes remain incompletely understood. This observational cross-sectional study explored the basis for variability of CD8+ T cell number and composition of its main subsets: naïve, central memory and effector memory T cells, in 131 cytomegalovirus (CMV) seropositive subjects aged over 60 years. We found great heterogeneity of CD8+ T cell numbers, which was mainly due to variability of the $\mathrm{CD} 8+\mathrm{CD} 28-\mathrm{T}$ cell subset regardless of age. Analysis, by multiple regression,
\end{abstract}

Electronic supplementary material The online version of this article (doi:10.1007/s11357-013-9594-z) contains supplementary material, which is available to authorized users.

R. Vescovini $(\bowtie) \cdot$ A. R. Telera $\cdot$ M. Pedrazzoni $\cdot$

F. Magalini · A. Stella F. Pasin $\cdot$ M. C. Medici

A. Calderaro $\cdot$ R. Volpi $\cdot$ P. Sansoni

Department of Clinical and Experimental Medicine,

University of Parma, via Gramsci 14, 43126 Parma, Italy

e-mail: rosanna.vescovini@unipr.it

\section{F. F. Fagnoni}

Immunohematology and Transfusion Center, Hospital of

Parma, Parma, Italy

L. Bucci $\cdot$ C. Franceschi

Department of Experimental, Diagnostic and Specialty

Medicine, University of Bologna, Bologna, Italy of distinct factors revealed that age was a predictor for the loss in absolute number of naïve $\mathrm{T}$ cells, but was not associated with changes in central or effector memory CD8+ T cell subsets. By contrast, the size of CD8+ T cells specific to pp65 and IE-1 antigens of CMV, predicted CD28-CD8+ T cell, antigen-experienced CD8+ T cell, and even total CD8+ T cell numbers, but not naïve CD8+ $\mathrm{T}$ cell loss. These results indicate a clear dichotomy between the homeostasis of naïve and antigen-experienced subsets of CD8+ T cells which are independently affected, in human later life, by age and antigen-specific responses to $\mathrm{CMV}$, respectively. 
Keywords Aging $\cdot$ Age $\cdot$ Cytomegalovirus .

Homeostasis · Memory CD8 T cell $\cdot$ Naïve CD8 T cell

\section{Introduction}

Altered immunity associated with aging, commonly defined as immunosenescence, is a potential contributor to increased morbidity and death in old age (Pawelec 2006; McElhaney and Effros 2009). The greatest alterations of the circulating $\mathrm{T}$ cell population are found within the CD8+ T cell branch and consist of an increase in antigen-experienced T cells with a CD28- late differentiated phenotype (Fagnoni et al. 1996; Weng et al. 2009) along with a shortage of naïve T cells (Fagnoni et al. 2000). Interestingly, subjects with prior cytomegalovirus (CMV) infection not only have a similar excess of CD8+CD28- (Looney et al. 1999; Almanzar et al. 2005; Weinberger et al. 2007; Chidrawar et al. 2009; Derhovanessian et al. 2010, 2011; Litjens et al. 2011) and fewer CD8+ naïve T cells (Almanzar et al. 2005; Weinberger et al. 2007; Chidrawar et al. 2009; Derhovanessian et al. 2010, 2011; Litjens et al. 2011; Sauce et al. 2009) in comparison with uninfected subjects, but also represent the vast majority of elderly people (Boeckh and Geballe 2011; Natali et al. 1997). Consequently, such age-related alterations of CD8+ T cell subsets are believed to be driven by CMV infection (Koch et al. 2007; van de Berg et al. 2008). However, many questions remain about effects of anti-CMV T cell responses on $\mathrm{T}$ cell homeostasis in aged subjects.

One basic question concerns the distinction between the relative effects of anti-CMV $\mathrm{T}$ cell responses and aging itself since it is not entirely clear whether CD8+ subsets alterations are also due to chronological age (PitaLopez et al. 2009) or rather depend solely on agedependent increasing prevalence of CMV seropositivity (Weinberger et al. 2007; Chidrawar et al. 2009). Also, there exists the formal possibility that CMV predominantly infects subjects that already exhibit subverted $\mathrm{T}$ cell pools and weakened immunity, which may, or may not, predispose them to CMV infection. Furthermore, when considering each single CD8+ subset, it has never been assessed whether all accumulated CD28-CD8+ T cells seen in infected subjects can recognize CMV (Weng et al. 2009), and whether their accumulation correlates with the size of anti-CMV T cell responses. In fact, CMV might drive indirect non-specific $\mathrm{T}$ cell differentiation, or accelerate age-dependent loss of homeostatic mechanisms, or the immune response against CMV could produce or contribute to an environment of inflammation, that could intensify antigen-dependent differentiation in response to other antigens. On the other hand, with regard to naïve T cells loss, inflated anti-CMV T cell responses may have a detrimental effect, but it remains to be seen whether naïve $\mathrm{T}$ cell loss is related to expansion of anti-CMV T cell responses and whether age and CMV infection may synergize to accelerate this loss.

Many such questions could be answered through evaluation of the overall magnitude of CMV-specific $\mathrm{T}$ cell responses, which unfortunately is an extremely demanding task because of the breadth of such responses. Functional assays with intracellular cytokine staining (ICS) in antigen-activated cells (Kern et al. 2000; Sylwester et al. 2005), and flow cytometry (FCM) staining assays with peptide-MHC (pMHC) multimers (Khan et al. 2002), both provide a partial determination of the CMV-specific T cell responses. Nevertheless, studies carried out so far with pMHC multimers (Khan et al. 2002, 2004; Ouyang et al. 2004; Vescovini et al. 2004), or with functional assays (Khan et al. 2004, 2007; Vescovini et al. 2007) both have reported consistent and significant increases in CD8+ CMV-specific memory/effector $\mathrm{T}$ cells in the elderly in comparison with younger subjects. Such results constitute a starting point to suggest that elderly subjects carrying CMV may have not only altered T cell homeostasis, but also altered immunity to heterologous viruses and impaired responses to vaccines. These associations are raising the appealing hypothesis that reducing the impact of CMV infection may improve immunocompetence and health by anti-CMV interventions (Demmler 2006; Moss 2010). Ultimately, to clarify this issue, the design of interventional anti-CMV trials would be required, but for this purpose it would be essential to define which endpoints are clearly dependent on CMV and may be still reversible and possibly targeted in CMVseropositive subjects even in advanced aging.

The scope of this observational cross-sectional study was to understand whether, which and how the altered profile of naive, memory and effector CD28-CD8+ $\mathrm{CD} 8+\mathrm{T}$ cell subsets in CMV-seropositive subjects aged over 60 years could depend on anti-CMV CD8+ T cell responses. To this end, we enumerated CD8+ T cells producing IFN-gamma following ex vivo stimulation with peptides covering the pp65 and IE-1 proteins, and CD8+ T cells identified by pMHC multimers to individual pp65 HLA-A2 and -B7 immunodominant epitopes, 
to see their relationship with the variability of each CD8+ T cell subset. Although analysis of this study was limited to only a small fraction of the overall antiCMV CD8 $+\mathrm{T}$ cells response, results indicated that numbers of anti-CMV CD8 $+\mathrm{T}$ cells had a significant impact upon variability of central/effector memory CD8+ T cells, but without significant effect on the naïve $\mathrm{CD} 8+\mathrm{T}$ cell reservoir, whose depletion worsened simply in line with age.

\section{Methods}

Subjects

The study was performed after approval from the Ethics Committee of the University of Parma. We contacted subjects aged $\geq 60$ years (range: $60-100$ years) and after written, informed consent, they received an extensive physical examination and answered standardized questionnaires to assess clinical history, current disease, current medication list, cognitive function, functional activity, lifestyle and socioeconomic status. Exclusion criteria were: evidence of endocrine, autoimmune and neoplastic diseases, acute infections or very recent infections (in the last 2 months), renal and liver failure and the use of medications known to modulate the immune responses (steroids, non-steroidal anti-inflammatory agents, acetyl salicylic acid $>100 \mathrm{mg}$ /day or other immunosuppressive drugs). Blood samples were drawn from all 131 subjects enrolled in the study, 79 females and 52 males, to perform the laboratory analyses.

Determination of CMV-specific antibody levels

CMV-specific IgM and IgG Ab levels were determined in serum samples from all donors. Indirect chemiluminescence immunoassays (CLIA), were used for the quantitative evaluation of anti-CMV IgM and IgG (Liaison CMV IgM and CMV IgG assays, DiaSorin, Vercelli, Italy). Samples were analyzed by a photomultiplier Liaison (DiaSorin), following the manufacturer's protocol.

Flow cytometric analysis of T cells phenotype

Surface staining was performed on heparinized whole blood using the following mAbs: anti-CD28-FITC, anti-CD95-PE, anti-CD3-PerCP and anti-CD8-APC or anti-CD4-APC (all from BD Biosciences, San Jose,
CA, USA). First, $100 \mu$ of blood was incubated with saturating amounts of the mAbs for $20 \mathrm{~min}$ on ice and then were lysed with FACS Lysing Solution (BD Biosciences). Six-parameter FCM acquisition and analysis were performed on a two-laser FACSCalibur instrument (BD Biosciences) using CellQuest software (BD Biosciences). Files were first gated on lymphocytes, identified by characteristic forward angle and side scatter profiles and $\mathrm{CD} 3+\mathrm{CD} 8+\mathrm{T}$ cells subsets were gated into naïve (CD28+CD95-), central memory $(\mathrm{CM}, \mathrm{CD} 28+$ CD95hi), and effector/effector memory (EM, CD28CD95hi) subsets, as previously published in human (Fagnoni et al. 2000) and in primate models (Pitcher et al. 2002). Isotype-matched irrelevant antibodies were used to set fluorescence markers and to identify nonspecific binding. To obtain the absolute numbers we used total lymphocyte counts from quality certified clinical laboratory analysis and FCM quantification of CD8+ T cell frequencies. The absolute numbers of total, naïve, $\mathrm{CM}$ and EM CD8+ T cells per $\mu \mathrm{l}$ of peripheral blood were calculated multiplying lymphocyte counts by the frequency of different subsets in the lymphocyte gate. In the multiple regression analysis, $\mathrm{CM}$ and $\mathrm{EM} \mathrm{CD8+} \mathrm{T}$ cells were considered separately or together, as antigenexperienced T cells (total memory, CD95hi), as indicated.

Assessment of functional anti-CMV CD8+ T cell responses by intracellular cytokine staining

Peripheral blood mononuclear cells $\left(\mathrm{PBMC}_{\mathrm{s}}\right)$ were obtained by Ficoll density gradient centrifugation (Biocoll Separating Solution; Biochrom AG, Berlin) from freshly drawn venous blood. After washing with phosphatebuffered saline (PBS), $\mathrm{PBMC}_{\mathrm{s}}$ were resuspended in RPMI 1640 medium supplemented with $10 \%$ fetal calf serum (FCS), $2 \mathrm{mmol} / \mathrm{lL}$-glutamine, $100 \mu \mathrm{g} / \mathrm{ml}$ streptomycin and 100 units $/ \mathrm{ml}$ penicillin (complete medium). In all experiments the cells were immediately stimulated with PepMix pp65 and PepMix IE-1 (JPT Peptide Technologies, Berlin, Germany), spanning the $65-\mathrm{kDa}$ lower matrix phosphoprotein and the $55-\mathrm{kDa}$ immediate-early protein 1 , respectively, and consisting of 15 amino acid long peptides, overlapped by 11 amino acids. Stimulation and intracellular cytokine detection was performed in accordance with the protocol recommended by JPT Peptide Technologies and well described (Vescovini et al. 2007). Briefly, $10^{6}$ PBMCs were placed in $15-\mathrm{ml}$ conical polypropylene tubes (Corning Incorporated, New York, USA) in a final 
volume of $500 \mu \mathrm{l}$ of complete medium and incubated with one test volume of each PepMix and $1 \mu \mathrm{g}$ each of the costimulatory mAbs CD28 and CD49d (BD Biosciences). Negative controls (incubation with antiCD28/CD49d but not with PepMixes) were included in every experiment to detect spontaneous production of cytokines. After $1 \mathrm{~h}$ of incubation in a standard incubator $\left(37^{\circ} \mathrm{C}\right.$, humidified $\mathrm{CO}_{2}$ atmosphere) each tube received $500 \mu \mathrm{l}$ of complete medium containing the protein transport inhibitor monensin (BD Golgi Stop, BD Biosciences). After an additional $4 \mathrm{~h}, \mathrm{PBMC}_{\mathrm{s}}$ were fixed, permeabilized and then stained with saturating amounts of antibodies anti-IFN- $\gamma$, anti-CD4 and antiCD8 (all from BD Biosciences). The samples were acquired and analyzed as described above. Files were gated on lymphocytes and cytokine-secreting populations and were defined as the percentage of the IFN $-\gamma^{+}$events gated on $\mathrm{CD} 8+\mathrm{T}$ cell population minus the percentage of the events falling into the same region in the corresponding control sample. We identified the sum of the frequencies of anti-pp65 and/or anti-IE-1 IFN $-\gamma$ producing $\mathrm{CD} 8+\mathrm{T}$ cells as the percentages of functional anti-CMV CD8+ among total CD8+. The absolute numbers of anti-CMV CD8+ T cells per $\mu$ of peripheral blood were calculated multiplying lymphocyte counts by the frequency of CD8 $+\mathrm{T}$ cells in the lymphocyte gate and by the frequency of IFN- $\gamma$ producing cells within total CD8+.

Assessment of anti-CMV CD8+ T cell responses by $\mathrm{pMHC}$ pentamer staining

All subjects were screened for HLA-A*02 and HLA$\mathrm{B} * 07$ alleles by FCM: positive donors were identified by using R-PE-conjugated anti-HLA-A2 and FITCconjugated anti-HLA-B7 monoconal antibodies (ProImmune Limited, Oxford, UK). PBMCs $\left(1 \times 10^{6}\right)$ from positive subject were incubated with saturating amounts of R-PE-conjugated HLA-A*0201/CMV pp65(495-503) (NLVPMVATV) and HLAB*0702/CMV pp65(417-426) (TPRVTGGGAM) pentamers (ProImmune). The cells were incubated for $10 \mathrm{~min}$ at room temperature in the dark, then washed in a wash buffer (PBS supplemented with bovine serum albumin and EDTA) and incubated with anti-CD3-PECy7, anti-CD8-APC and anti-CD28-FITC mAbs (B.D. Biosciences), for $30 \mathrm{~min}$ on ice in the dark. The samples were then washed and acquired by FCM. In singlepositive donors we identified the frequencies of CD8+
T cells positive for $A^{*} 0201 / \mathrm{CMV}$ pp65(495-503) or HLA-B*0702/CMV pp65(417-426) pentamers as the percentage of anti-pp65pentamers $+\mathrm{CD} 8+\mathrm{T}$ cells among total CD8; in double-positive donors we identified the frequencies of CD8+ T cells positive for both immunodominant epitopes, added them and expressed them as the percentage of anti-pp65pentamers + CD8 $+\mathrm{T}$ cells among total CD8+ T cells. The absolute numbers per $\mu$ of peripheral blood were calculated multiplying lymphocyte counts by the frequency of CD8+ in the lymphocyte gate and by the frequency of antipp65pentamer $+\mathrm{CD} 8+\mathrm{T}$ cells within total $\mathrm{CD} 8+$. We analyzed also the expression of CD28 molecule among the anti-pp65pentamer+ $\mathrm{T}$ cells, determining the percentages and the absolute numbers of the two subsets of antipp65pentamer+CD28+ CM and anti-pp65pentamer+ CD28- EM T cells.

Statistical analysis

Statistical analysis was performed using StatView and SPSS softwares. 0.05 was the alpha level at which $p$ values were considered statistically significant. CMV-specific IgG values were represented as ranktransformed data. Correlations between age, size of $\mathrm{CD} 8+\mathrm{T}$ cell subsets and anti-CMV responses were tested using the Spearman's rank correlation coefficient.

In order to investigate the contribution of several variables on CD8+ T cell subsets (number of total, naïve, and antigen-experienced CD8+ T cells), we used multiple regression analyses. In our model-building strategy, age and CMV infection were considered a priori as main exposures of interest, and others predictors, identified as the more biologically relevant among the available data, were considered as covariates included to adjust for potential sources of confounding. We examined the following predictors: age, functional anti-CMV CD8+ T cell absolute number, anti-pp65pentamer+T cell absolute number, anti-CMV IgG titer, gender, educational level and health status. In these models, educational level (self-reported number of years spent at school) was used as an indirect socioeconomic status indicator and the variable was treated as continuous. The subject's health status was considered as a categorical variable, which could only take one of two values: healthy subject/unhealthy subject. Interview at the enrolment, physical examination, current medication list and results of laboratory analyses were used by trained clinicians to diagnose diseases, with the diagnosis based on established and widely recognized 
criteria. "Healthy subjects" were defined as subjects without evidence of diseases with the possible exception of mild hypertension or osteoarthritis, without cognitive impairment (Mini Mental State Examination [MMSE] >21), without functional impairment (no more than one compromised activities of daily living [ADL], Katz index), without hemato-chemical alterations and not taking any medication with the possible exception of antihypertensive therapy. "Unhealthy subjects" were defined as subjects that did not meet one or more of the previously indicated conditions and so could not be considered "healthy subjects".

We used backward elimination to identify the significant predictors and we presented multiple regression analyses only with the significant predictors.

\section{Results}

Variability of CD8 T cells in subjects aged over 60 years with prior CMV infection

We studied $131 \mathrm{CMV}$-infected subjects aged over 60 years (mean age, $81.3 \pm 10.3$, range $60-100$ ), all of whom were negative for CMV-IgM, but positive for CMV-IgG. We first determined percentages and absolute numbers of peripheral blood leukocytes, lymphocytes, CD3 $+\mathrm{T}$ cells, CD4 $+\mathrm{T}$ cells, CD8 $+\mathrm{T}$ cells (Table 1) and among total CD8+ T cells, percentages and numbers of three main subsets including naïve (CD28+CD95-), CM (CD28+CD95hi) and EM (CD28-CD95hi) (Fig. 1a). We observed wide variability of the whole CD8+ T cell numbers (10th-90th \%= 146-753 cells/ $\mu$ l; Table 1 and Fig. 1d). By contrast, the naïve $\mathrm{CD} 8+\mathrm{T}$ cell percentage and absolute number were constantly low with limited variability (median= $6 \%, 10-90$ th $\%=1-21 \%$ and median $=18.4 \mathrm{cells} / \mu \mathrm{l}$, 10th-90th $\%=4-68$ cells $/ \mu$, respectively) (Fig. 1b). Interestingly, the two subsets of antigen-experienced CD8+ $\mathrm{T}$ cells showed a distinct pattern: greater interindividual variability of CD28-CD95hi EM T cell numbers $(10$ th -90 th $\%=53-524$ cells $/ \mu \mathrm{l})$ as compared to CD28+CD95hi CM T cell numbers (10th-90th \%= 45-224 cells/ $\mu$ l) (Fig. 1d). Notably, it was observed that both percentages and numbers of total CD8+ T cells were mostly dictated by variation of CD28- EM CD8+ $\mathrm{T}$ cells (Fig. 1c, e). Collectively, these results indicated that $\mathrm{CMV}+$ aged subjects exhibited broad variability in
Table 1 Study subject characteristics

\begin{tabular}{ll}
\hline & Value \\
\hline Number of subjects & 131 \\
Age [y, mean (min-max)] & $81.3(60-100)$ \\
Gender (\% of females) & 60.3 \\
CMV-IgM (\% of positive) & 0 \\
CMV-IgG rank [IU/ml, median & $66(1-131)$ \\
(min-max)] & \\
Peripheral leukocyte populations: & $6,000^{\mathrm{a}}(3,400-11,030)$ \\
WBC & $29.8^{\mathrm{b}}(7.8-48.6)$ \\
Lymphocyte & $1,76^{\mathrm{a}}(450-2,900)$ \\
& $68^{\mathrm{c}}(43.7-88)$ \\
CD3+ & $1,185.7^{\mathrm{a}}(210-2,549)$ \\
& $64.3^{\mathrm{d}}(15.8-87.3)$ \\
CD4+ & $743.5^{\mathrm{a}}(98-1,602.6)$ \\
& $30.8^{\mathrm{d}}(10.5-83.2)$ \\
CD8+ & $340.8^{\mathrm{a}}(50-1,009.4)$ \\
& $6^{\mathrm{e}}(0.04-54.1)$ \\
& $18.4^{\mathrm{a}}(0.13-140.7)$ \\
Naive CD8+ & $37^{\mathrm{e}}(5.9-85.6)$ \\
& $115.3^{\mathrm{a}}(17-423)$ \\
CM CD8+ & $53.5^{\mathrm{e}}(6.6-92)$ \\
& $173.4^{\mathrm{a}}(5.8-794)$ \\
\hline
\end{tabular}

Naïve, CM and EM CD8+ subsets are defined in "Methods"

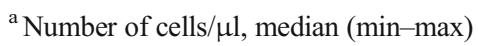

$\mathrm{b}_{\%}$ among WBC, median (min-max)

$\mathrm{c}_{\%} \%$ among total Lymphocyte, median (min-max)

$\mathrm{d}_{\%}$ among total $\mathrm{CD} 3+$, median (min-max)

e $\%$ among total CD8+, median (min-max)

CD8 + T cell number, which mainly reflected the variability in their CD28-CD95hi compartment.

Progressive age correlates with the loss of naïve CD8 T cells in $\mathrm{CMV}+$ subjects

The effect of age on inter-individual T cell and CD8+ subset variability was explored by correlating the percentages (Fig. S1) and the absolute numbers (Fig. 2) of each subset with the age of the subjects. We found that percentages of lymphocytes significantly decreased with age, while the percentages of CD3+, CD4+ and CD8+ T cells did not significantly change (Fig. S1a-d). As expected, amongst the CD8+ T cell compartment, a significant age-related decrease in the naïve $T$ cell percentages was mirrored by an increase in the antigen-experienced $\mathrm{T}$ 
a

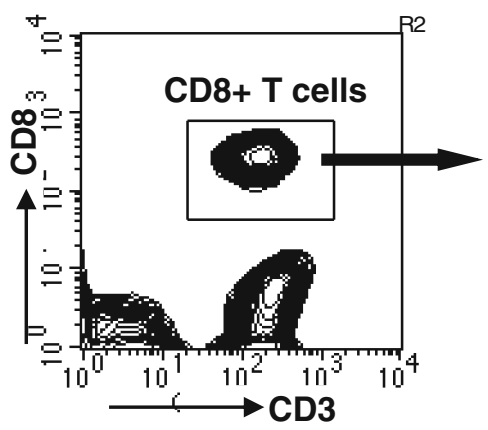

b

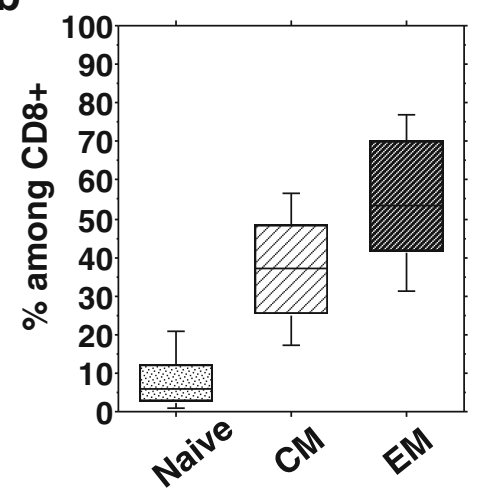

d

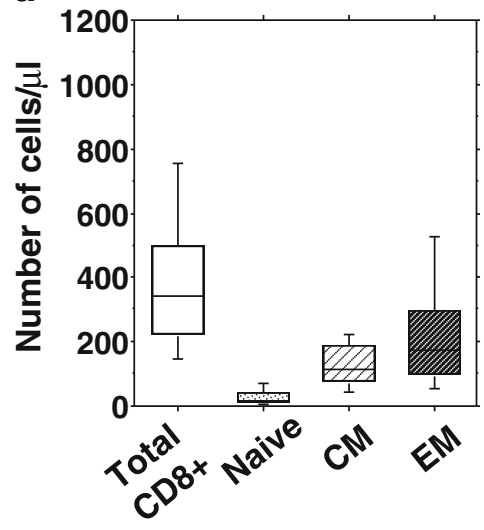

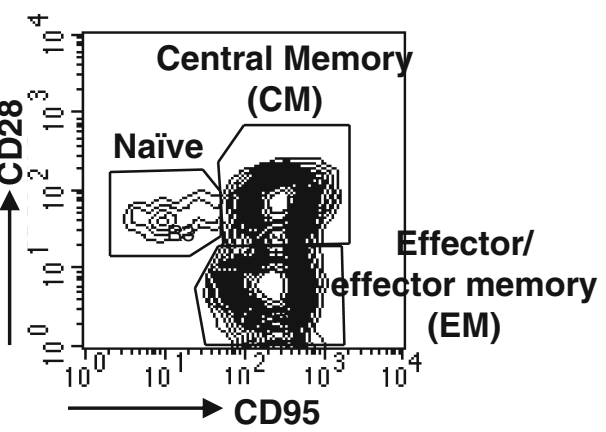

C

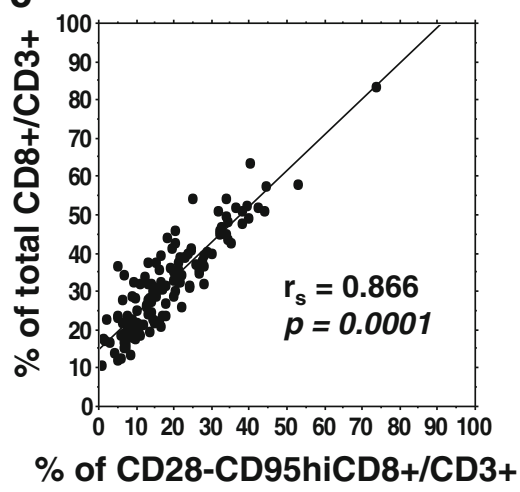

e

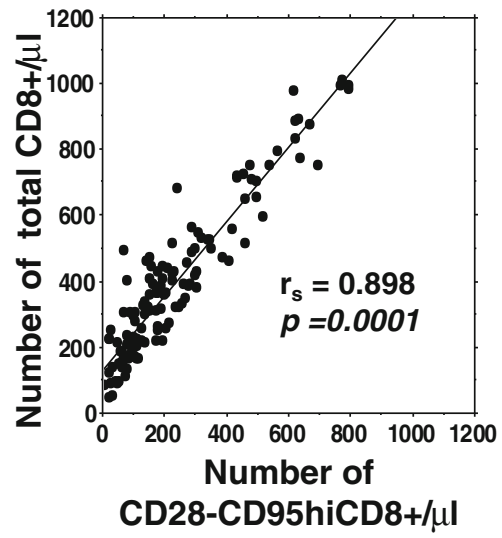

Fig. 1 Variability of CD8 T cell subsets in CMV-infected subjects aged over 60 years. a Representative flow cytometry plots of phenotypic analysis from a 79-year-old old subject. Heparinized whole blood were stained as described in "Methods". b Box plots show the percentages and $\mathbf{d}$ absolute numbers (median, 25th and 75 th percentiles, and bars above and below the box, the 10th and 90th percentiles) of total and different CD8 + T cell subsets, determined in all subjects. $\mathbf{c}$ The correlations of percentages and $\mathbf{e}$ absolute numbers of total CD8+ T cells with CD28- EM T cells were assessed by Spearman's rank test. In each plot, Spearman's rank correlation coefficient $\left(r_{\mathrm{s}}\right)$ and the line of best fit are shown. A $p$ value $<0.05$ was considered significant cell percentages (Fig. S1e, f). Interestingly, this accumulation reflected the increase in CD28- EM T cell percentages, while CD28+CM T cell percentages did not change (Fig. S1g, h). When we looked at the absolute numbers (Fig. 2), we found several different results: total lymphocytes and also absolute numbers of $\mathrm{CD} 3+$ and 


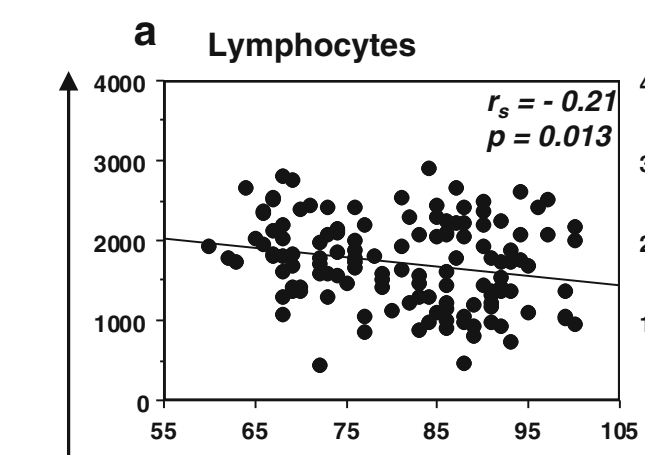

b CD3+
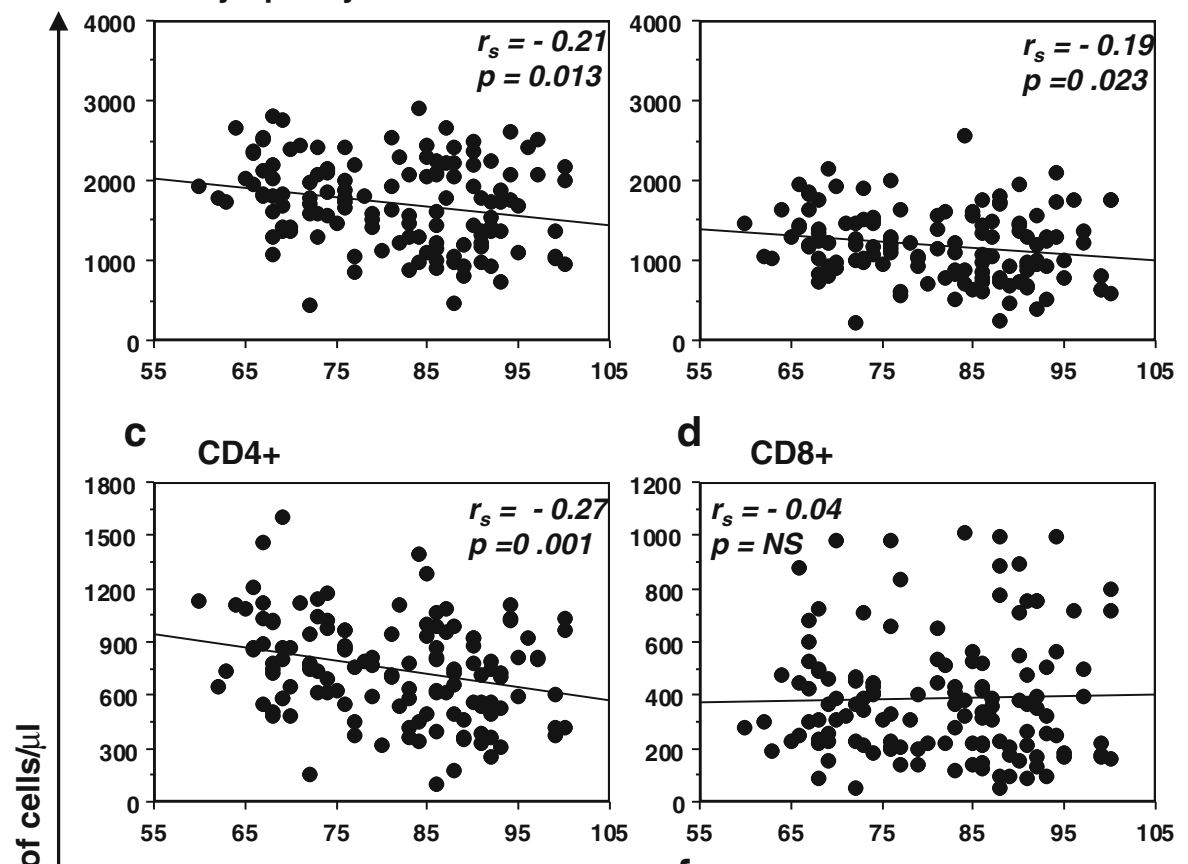

d CD8+
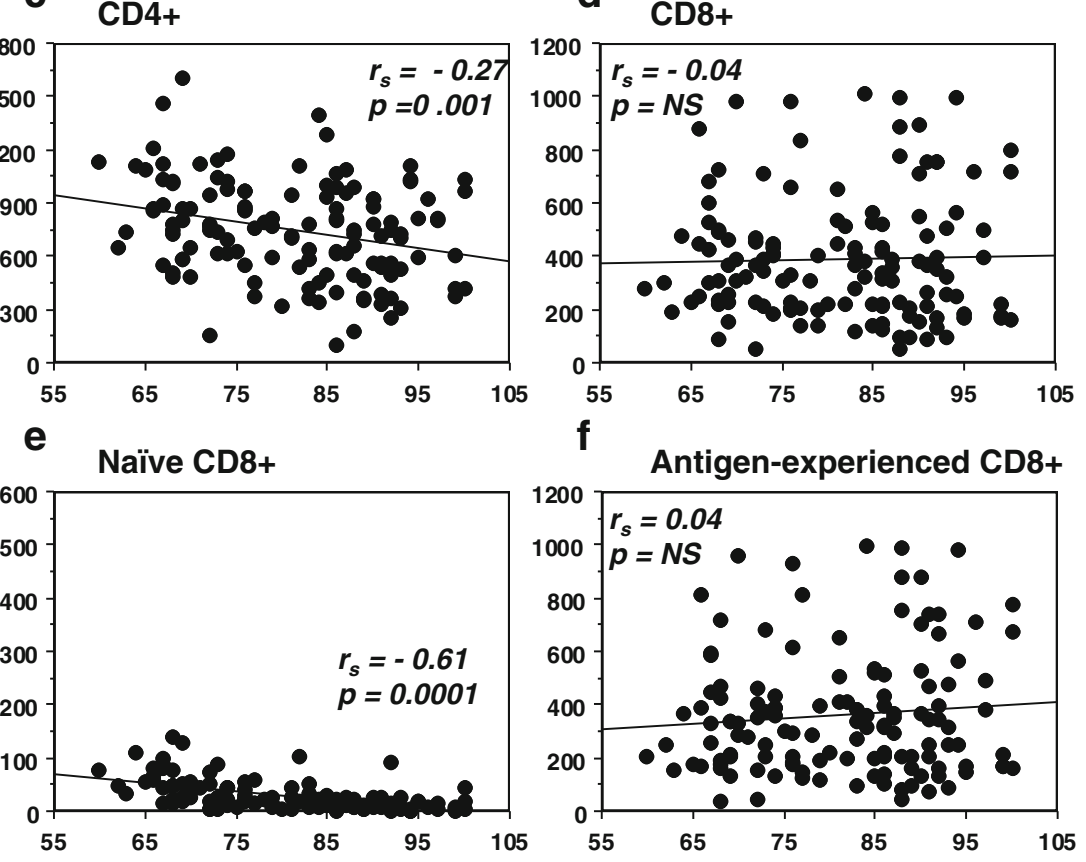

f Antigen-experienced CD8+

\section{흘}
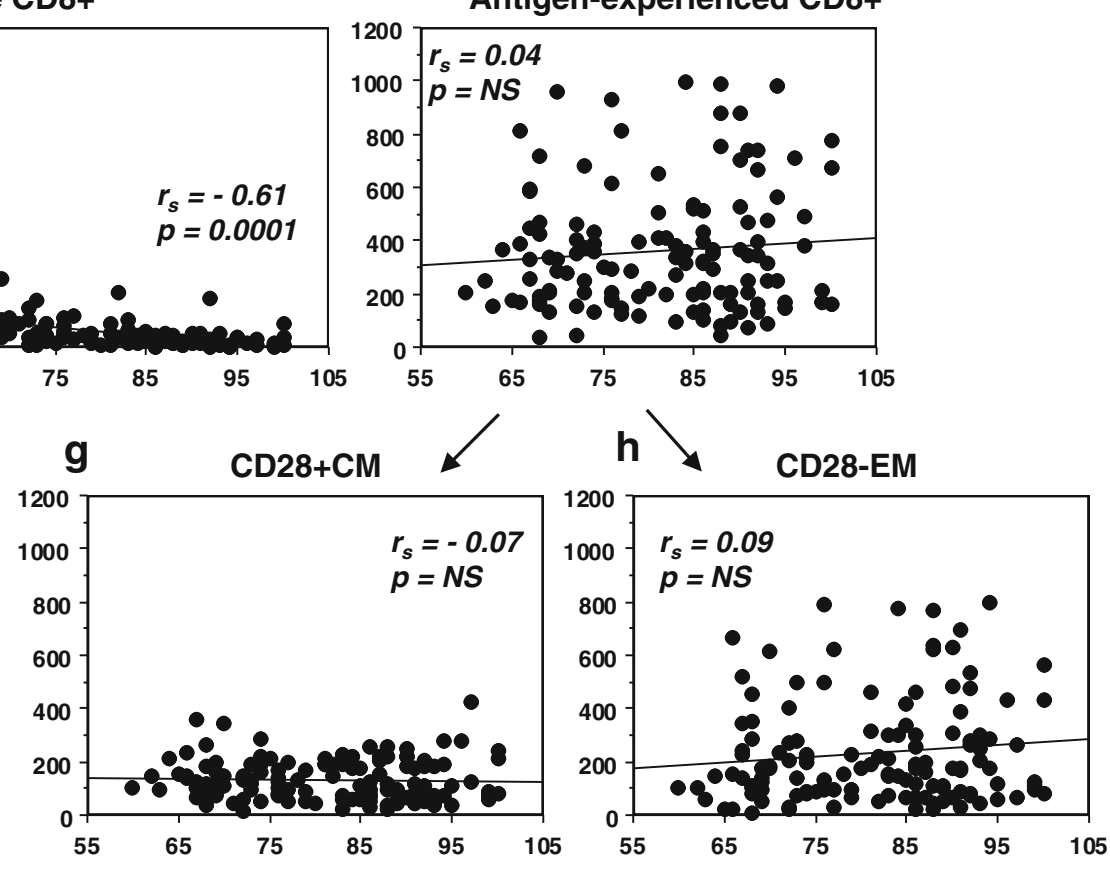

Age (y)

Fig. 2 Relationship between age and alterations in CD8 T cell subset abundance. Absolute numbers of each circulating population are represented in correlation with the subject age. All the correlations were assessed by Spearman's rank test. Spearman's rank correlation coefficients $\left(r_{\mathrm{s}}\right)$ and the line of best fit are shown. $p$ values $<0.05$ were considered significant 
CD4+ T cells significantly decreased with age (Fig. 2a-c), while the numbers of CD8+ T cells did not significantly change (Fig. 2d). Amongst the CD8+ T cell subset, naïve $\mathrm{CD} 8+\mathrm{T}$ cell numbers progressively declined with age (Fig. 2e). By contrast, antigen-experienced CD8+ T cell numbers, including both the CD28+CM and CD28- EM $\mathrm{T}$ cell numbers, did not significantly change within this interval (Fig. 2f, g, h). Hence, CMV+subjects aged over 60 years exhibited a significant age-related reduction of naïve CD8+ T cells, both as percentage and as absolute number, whereas the antigen-experienced $\mathrm{T}$ cell expansion was only in terms of percentages, without age-related absolute modifications of either CM or EM CD8 T cells.

Numbers of CD8 + T cells reactive to pp65 and IE-1 correlate with the accumulation of the antigen-experienced CD8 T cells

One of the main objectives of the study was to obtain insights into the impact of anti-CMV CD8+ T cell responses on CD8+ $\mathrm{T}$ cell subsets distribution. To this end, we used both pMHC multimer staining and functional ICS assays. pMHC multimers detect antigen-specific responses to selected HLA-class I restricted immunodominant epitopes, whereas ICS measure global responses to entire proteins, using peptide mixes covering the entire protein length. For these latter assays, we stimulated the PBMC of all recruited donors with the commercially available peptide mixes covering pp65 and IE-1 CMV proteins, to evaluate the percentage (Fig. S2) and the absolute number of antigen-specific IFN- $\gamma$ producing CD8 + T-cells (Fig. 3a). In 100 of 131 subjects (76.3\%) who had a pp65- and/or a IE-1-specific response, we correlated the absolute numbers of functional antigen-specific CD8+ T cells with the absolute number of CD8+ T cells, naïve and antigen-experienced (total memory) CD8 $+\mathrm{T}$ cells (Fig. 3b). Absolute numbers of IFN $\gamma+$ antigen-specific CD8+ T cells exhibited significant positive correlation to both CD8+ T cell absolute number and total memory (CD95hi) CD8+ T cell absolute number, but showed no correlation to the number of naive $\mathrm{CD} 8+\mathrm{T}$ cells. In subjects bearing HLA-A2 and/or -B7, staining with the HLAA*0201/CMV pp65(495-503) and HLA$\mathrm{B}^{*} 0702 / \mathrm{CMVpp} 65(417-426)$ and CD28 allowed us to separate anti-pp65pentamer+T cells into antigen-specific CD28+ CM and CD28- EM T cells (Fig. 3c). 51/67 subjects $(76.1 \%$, ) had anti-pp65pentamer+CD8+ T cells that we could correlate with absolute number of the CD8+ $\mathrm{T}$ cell subsets. Similarly to functional responses, overall
Fig. 3 Relationship between anti-CMV CD8+ T cell responses and alterations in CD8 $\mathrm{T}$ cell subset abundance. a Representative flow cytometry plots of functional anti-CMV CD8+ T cells from a 76year-old subject. PBMCs were stimulated for $5 \mathrm{~h}$ with mixtures of peptides spanning the sequence of pp65 and IE-1 CMV proteins and stained as described in "Methods". b Absolute numbers of each CD8 + T cell subset are represented in correlation with the absolute numbers of functional anti-CMV CD8+ T cells, identified as the sum of anti-pp65 and anti-IE-1 IFN- $\gamma$ producing CD8+ T cells. c Representative flow cytometry plots of anti-pp65 pentamer+CD8+ T cells from an 85-year-old subject. PBMC $\mathrm{S}_{\mathrm{s}}$ of HLA-A2 (not shown) and HLA-B7 positive subjects (this panel) were stained with p-MHC anti-pp65pentamers as described in "Methods". d Absolute numbers of each CD8+ T cell subset are represented in correlation with the absolute numbers of anti-pp65pentamer $+\mathrm{CD} 8+\mathrm{T}$ cells. e The antigen-experienced CD8+ T cells are dissected to depict CD28+ CM and CD28- EM T cells and absolute numbers are represented in correlation with the absolute numbers of anti-pp65pentamer+ CD28+ CM T cells and anti-pp65pentamer+CD28- EM T cells. All the correlations were assessed by Spearman's rank test. The Spearman's rank correlation coefficients $\left(r_{\mathrm{s}}\right)$ and the line of best fit are shown. Both the functional anti-CMV and anti-pp65pentamer+ CD8+ T cell absolute numbers are shown in a log-scale. $p$ values $<0.05$ were considered significant

anti-pp65pentamer $+\mathrm{CD} 8+\mathrm{T}$ cell absolute number exhibited significant positive correlation to both the CD8+ T cell absolute number and the antigen-experienced CD8+ T cell absolute number, again without significant correlation with naïve CD8+ T cell numbers (Fig. 3d). Delineation of antipp65pentamer+CD8+ T cell according to CD28 expression showed a significant positive correlation both between antigen-specific and total CD28+ CM T cell subset and between antigen-specific and total CD28- EM T cell subset (Fig. 3e). In summary, these results strongly indicated that number of functional anti-pp65 plus IE-1 CD8+ $\mathrm{T}$ cells, as well as the number of anti-pp65pentamer+ CD8+ $\mathrm{T}$ cells, were related to absolute number of total antigen-experienced CD8+ T cells, but not to naïve CD8+ $\mathrm{T}$ cell number.

Relationship between age and anti-CMV immune responses in study subjects

Memory inflation of anti-CMV CD8+ T cell responses during human aging has been reported by several studies comparing elderly to middle aged and young subjects. Nevertheless, it is unclear whether such a tendency to accumulate anti-CMV CD8 $+\mathrm{T}$ cell responses is further modulated by aging. As shown in Fig. 4, when we correlated the anti-CMV CD8+ T cells with age in our cohort of donors aged over 60 years, neither the percentages nor 
a

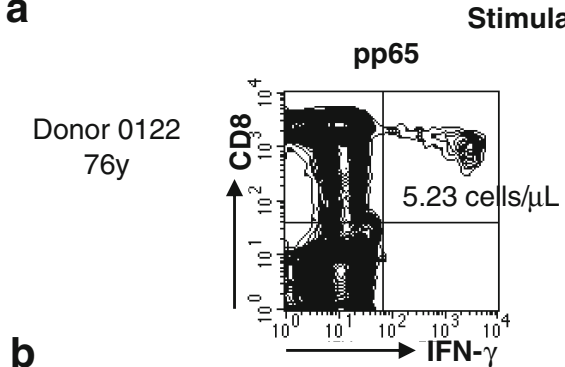

Stimulation with
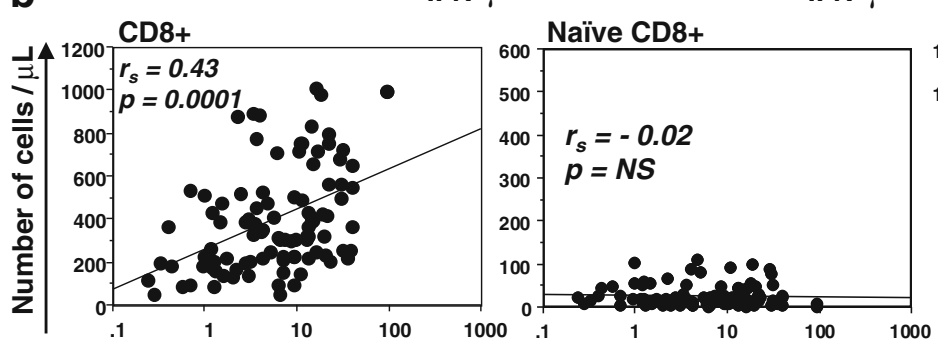

IE-1
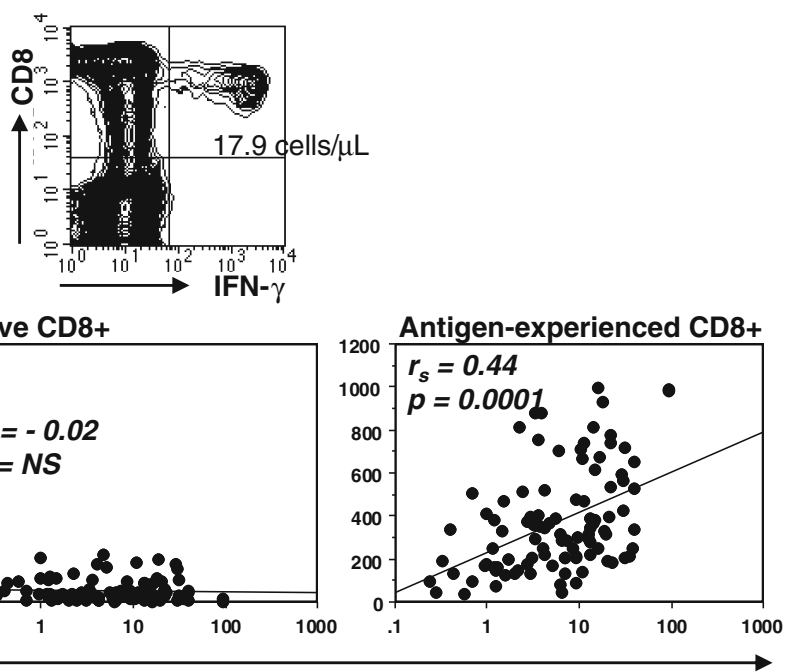

Number of functional anti-CMV CD8+/ $\mu \mathrm{L}$

C

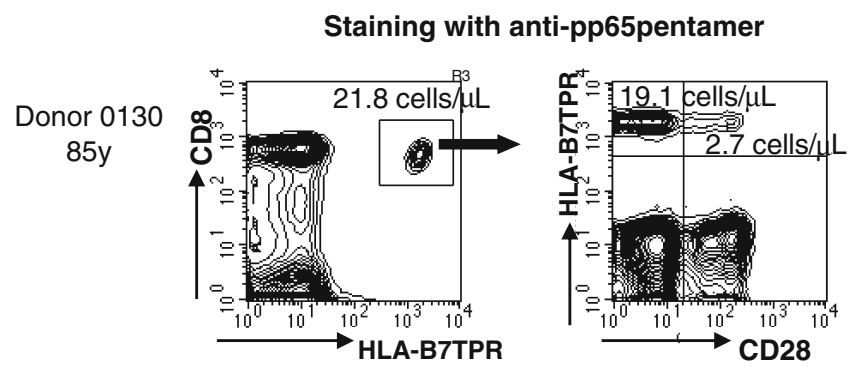

d
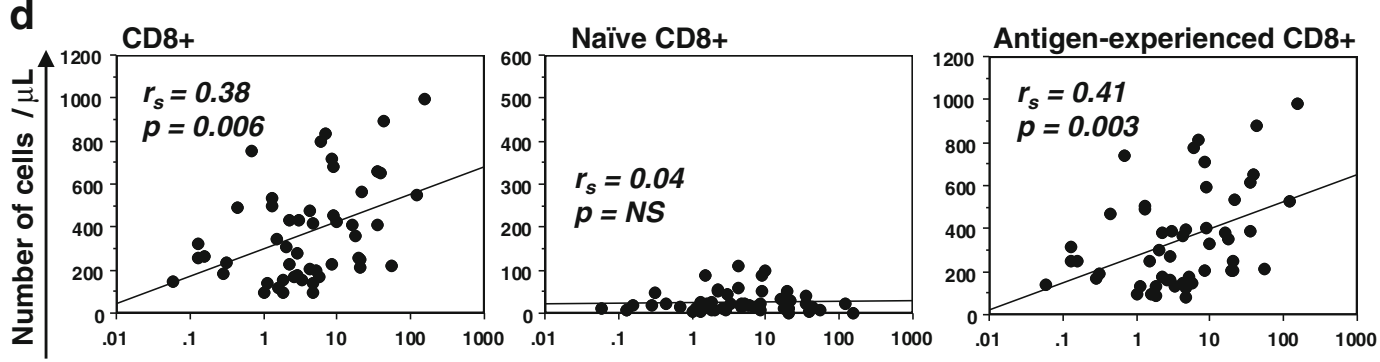

Number of anti-pp65pentamer+ CD8+/ $\mathrm{LL}$
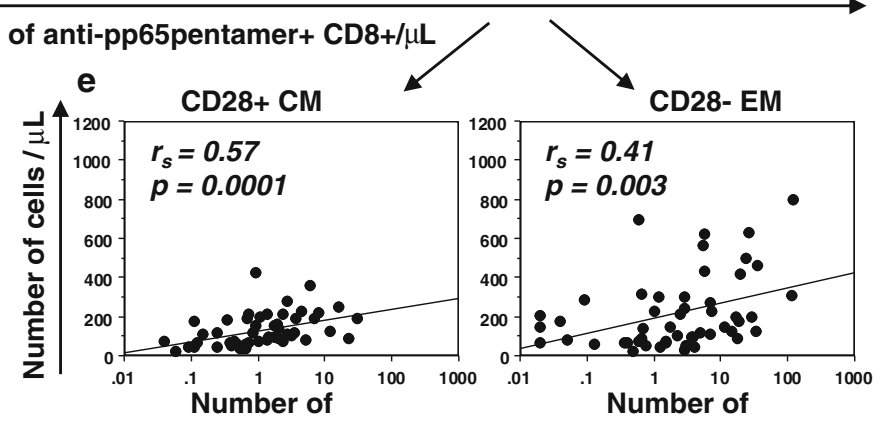

anti-pp65pentamer+CD28+/ $\mu \mathrm{L}$ anti-pp65pentamer+CD28-/ $\mu \mathrm{L}$ 
absolute numbers of anti-CMV CD8+ T cells, evaluated as functional (Fig. 4a, b) or as anti-pp65pentamer+ (Fig. 4c, d) T cells, significantly changed with age. The same result was found when considering percentages or absolute numbers of anti-pp65pentamer $+\mathrm{CM} \mathrm{T}$ cells (Fig. 4e, f) and anti-pp65pentamer+EM T cells (Fig. 4g, h). Thus, data did not highlight any further increase in anti-CMV CD8+ T cell responses during the last decades of life. Rather, the values of anti-CMV CD8+ $\mathrm{T}$ cell responses indicated broad inter-individual variability $(10$ th -90 th $\%=1-30$ cells $/ \mu$ and $0.3-37$ cells $/ \mu 1$, respectively, for functional and anti-pp65 $\mathrm{T}$ cell absolute numbers), which was not related to age. When we considered anti-CMV humoral responses, as previously described, a significant age-related increase of CMVspecific IgG was found (Fig. S3). Interestingly, the correlations of CMV-specific IgG with both the percentages or the absolute numbers of functional anti-CMV CD8+ T cells (Fig. S3b, c) as well as with both percentages and absolute numbers of anti-pp65pentamer $+\mathrm{CD} 8+\mathrm{T}$ cells (Fig. S3d, e), were not significant. These results underlined the lack of a significant association between the anti-CMV humoral response intensity and the CMVspecific CD8+ T cell responses evaluated in this study.

Multiple regression models to investigate

the inter-individual variability of CD8+ T cell subsets

In order to investigate the basis for the broad interindividual variability of $\mathrm{CD} 8+\mathrm{T}$ cell subsets, we tested the contribution of several variables through multiple regression analyses. In a preliminary analysis we examined all the following predictors: age, either functional anti-CMV CD8 $+\mathrm{T}$ cell absolute number or antipp65pentamer+ $\mathrm{T}$ cell absolute number, anti-CMV IgG titer, gender, educational level and health status. By using backward elimination we found that the dependent variables (number of total, naïve, and antigen-experienced CD8+ T cells), were significantly predicted only by age and number of anti-CMV CD8+ T cell, but not by antiCMV IgG Ab level, gender, educational level or health status (data not shown). On this basis, we present the results with only age and anti-CMV CD8+ T cells as predictors for variability of CD8+ T cell subsets. Results shown in Table 2 highlight that: (a) functional anti-CMV CD8 + T cell absolute number was a significant predictor of the whole CD8+ T cell absolute number $\left(R^{2}=0.197\right.$, $p=0.0001)$, regardless of age; (b) age was a significant predictor of naïve CD8 $+\mathrm{T}$ cell absolute number $\left(R^{2}=\right.$
Fig. 4 Relationship between age and anti-CMV CD8+ T cell responses in advanced aging. a Percentages and $\mathbf{b}$ absolute numbers of functional anti-CMV T cell responses are correlated with age. c Percentages and $\mathbf{d}$ absolute numbers of anti-pp65pentamer $+\mathrm{T}$ cells are correlated with age. Anti-pp65pentamer+T cells were separated to denote anti-pp65pentamer+CM and anti-pp65pentamer+EM T cells and percentages (e and $\mathbf{f}$, respectively), or absolute numbers ( $\mathbf{g}$ and $\mathbf{h}$, respectively), are represented in correlation with age. All the correlations were assessed by Spearman's rank test. The Spearman's rank correlation coefficients $\left(r_{\mathrm{s}}\right)$ and the best fit are shown. Both the functional anti-CMV and anti-pp65pentamer $+\mathrm{CD} 8+\mathrm{T}$ cell absolute numbers are shown in a log-scale. $p$ values $<0.05$ were considered significant

$0.308, p=0.0001)$ with a reduction of 1.4 naïve $\mathrm{T}$ cells $/ \mu \mathrm{l}$ per year (95\% confidence interval: -0.97 to 1.83$)$, regardless of CMV-specific CD8+ T cell absolute number; (c) functional anti-CMV CD8+ T cell absolute number was a significant predictor of antigen-experienced (total memory) $\mathrm{CD} 8+\mathrm{T}$ cell absolute number $\left(R^{2}=\right.$ $0.214, p=0.0001$ ), regardless of age. The same analysis using the pMHC multimer assay (Table 3), showed that: (a) anti-pp65pentamer $+\mathrm{T}$ cell absolute number was a significant positive predictor of the absolute accumulation of CD8+ T cells $\left(R^{2}=0.222, p=0.0006\right)$, regardless of age; (b) age was a significant predictor of the absolute loss of naïve CD8+ T cells $\left(R^{2}=0.488, p=0.0001\right)$, regardless of the anti-pp65pentamer+T cell absolute number; (c) anti-pp65pentamer+T cell absolute number was a significant predictor of antigen-experienced (total memory) CD $8+\mathrm{T}$ cell absolute number $\left(R^{2}=0.23, p=0.0005\right)$, regardless of age. In addition, separate evaluation of antipp65pentamer+EM CD8+ T cells made it possible to define epitope-specific CD28- T cells as an independent predictor of absolute numbers of total EM CD8+ cells $\left(R^{2}=0.213, p=0.0014\right)$, regardless of age. By contrast, anti-pp65pentamer+CM $\mathrm{T}$ cell absolute number could not significantly predict variation of total CM CD8+ T cell absolute numbers $\left(R^{2}=0.076, p=0.0691\right)$.

\section{Discussion}

The impact of CMV infection on human immune function and health in later life is a subject of intense current research (Pawelec et al. 2010). It has been hypothesized that the manner in which CMV and the host immune system interact may be critical in determining the age and/or functional fitness of adaptive immunity and hence human longevity (Gress and Deeks 2009; Pawelec et al. 2006). Then, a challenge is to discriminate 
a Functional anti-CMV CD8+

|
C Anti-pp65pentamer+ CD8+

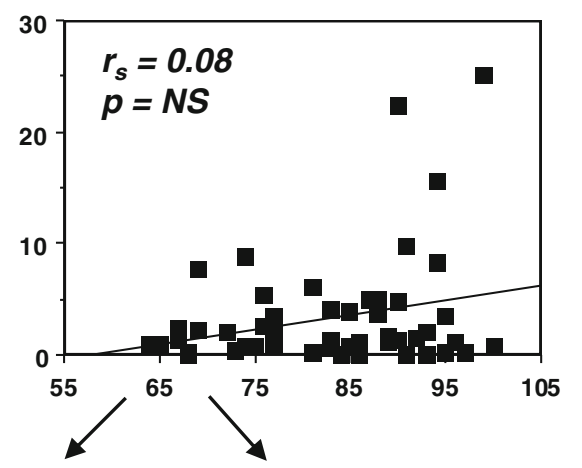

e Anti-pp65pentamer+CD28+ CM

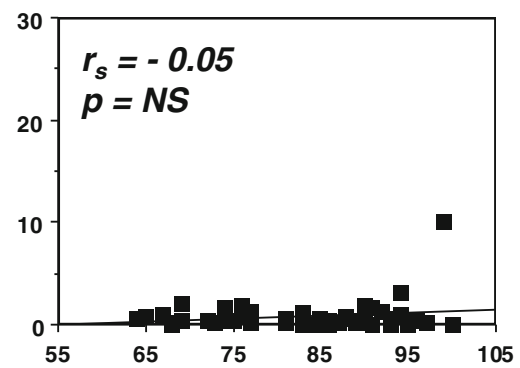

9 Anti-pp65pentamer+CD28- EM

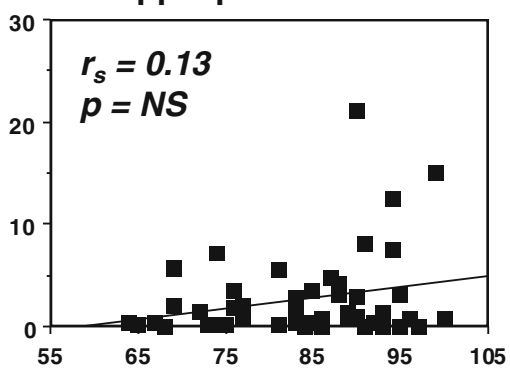

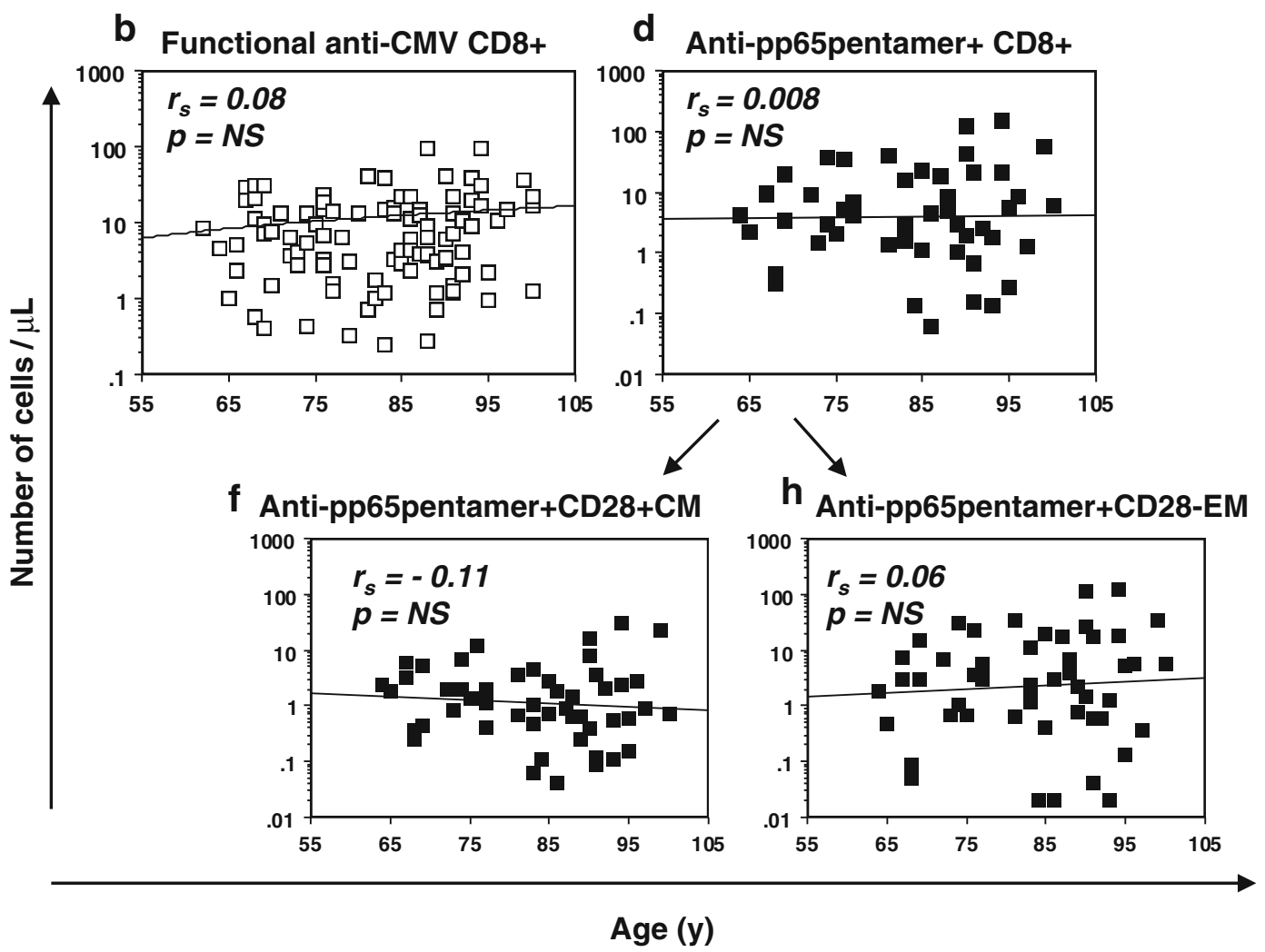


Table 2 Multiple regression analysis fitting age and functional anti-CMV CD8+ T cell absolute number as predictors for $\mathrm{CD} 8+\mathrm{T}$ cell subset absolute numbers

\begin{tabular}{|c|c|c|c|}
\hline & $\beta$ coefficient & $p$ value & $95 \%$ CI \\
\hline \multicolumn{4}{|l|}{ CD8+ T cell } \\
\hline Age & 0.879 & 0.6988 & $(-3.616,5.374)$ \\
\hline Number of functional anti-CMV CD8+ T cell/ $\mu \mathrm{l}$ & 6.719 & 0.0001 & $(3.97,9.613)$ \\
\hline \multicolumn{4}{|l|}{ Naïve CD8+ T cell } \\
\hline Age & -1.4 & 0.0001 & $(-1.829,-0.972)$ \\
\hline Number of functional anti-CMV CD8+ T cell/ $\mu 1$ & -0.018 & 0.8953 & $(-0.287,0.251)$ \\
\hline \multicolumn{4}{|l|}{ Antigen-experienced CD8+ T cell } \\
\hline Age & 2.274 & 0.3081 & $(-2.131,6.679)$ \\
\hline Number of functional anti-CMV CD8+ T cell $/ \mu \mathrm{l}$ & 6.775 & 0.0001 & $(4.01,9.54)$ \\
\hline
\end{tabular}

and quantify the contribution of CMV-immune system interaction from the sole effects of aging itself. This cross-sectional study provides new insights into the specific influences of aging and anti-CMV responses shaping peripheral blood CD8 $+\mathrm{T}$ cell subset homeostasis in CMV-seropositive subjects in their last four decades of life. In particular, we contribute to define a clear separation between forces dictating the altered profile of naïve and antigen-experienced $\mathrm{CD} 8+\mathrm{T}$ cell subsets in the elderly with CMV.

This study showed that anti-CMV specific CD8+ T cells responses may not further increase with advancing age. In the mouse models of herpesvirus infection, "memory inflation" has been shown to depend on viral antigen (Snyder et al. 2008; Lang et al. 2009) and modulated by the control of viral replication (Lang et al. 2009), but the age of the animal may not be predictive of the extent of inflation (Lang and Nikolich-Zugich 2011). Also, an observational crosssectional study in the rhesus macaques model (CicinSain et al. 2011) has revealed a rather constant magnitude of anti-CMV CD8+ T cell responses in later life. Even previous studies in humans have shown findings consistent with this notion. Khan et al. (2004) had reported more significant age-related increases in pMHC-measured anti-CMV CD8+ responses to multiple immunodominant epitopes between young (2040 years) and adults ( $40-60$ years), than between adults and aged subjects ( $>60$ years). Likewise, in a previous study of ours (Vescovini et al. 2007) showing agerelated expansion of cumulative anti-CMV CD4+ and $\mathrm{CD} 8+$, IFN- $\gamma$ and TNF- $\alpha$ producing $\mathrm{T}$ cells, the
Table 3 Multiple regression analysis fitting age and antipp65pentamer $+\mathrm{T}$ cell absolute number as predictors for $\mathrm{CD} 8+\mathrm{T}$ cell subset absolute numbers

\begin{tabular}{|c|c|c|c|}
\hline & $\beta$ coefficient & $p$ value & $95 \% \mathrm{CI}$ \\
\hline \multicolumn{4}{|l|}{ CD8+ T cell } \\
\hline Age & -2.009 & 0.5099 & $(-8.092,4.075)$ \\
\hline Number of anti-pp65pentamer $+/ \mu \mathrm{l}$ & 3.906 & 0.0006 & $(1.783,6.03)$ \\
\hline \multicolumn{4}{|l|}{ Naïve CD8+ T cell } \\
\hline Age & -1.795 & 0.0001 & $(-2.343,-1.247)$ \\
\hline Number of anti-pp65pentamer $+/ \mu 1$ & -0.014 & 0.887 & $(-0.205,0.178)$ \\
\hline \multicolumn{4}{|l|}{ Antigen-experienced CD8+ T cell } \\
\hline Age & -0.216 & 0.9428 & $(-6.226,5.795)$ \\
\hline Number of anti-pp65pentamer $+/ \mu \mathrm{L}$ & 3.885 & 0.0005 & $(1.787,5.983)$ \\
\hline \multicolumn{4}{|l|}{ CD28+ CM CD8+ T cell } \\
\hline Age & -1.195 & 0.3183 & $(-3.577,1.188)$ \\
\hline Number of pp65pentamer $+\mathrm{CD} 28+\mathrm{CM} / \mu 1$ & 3.857 & 0.0691 & $(0.314,8.027)$ \\
\hline \multicolumn{4}{|l|}{ CD28- EM CD8+ T cell } \\
\hline Age & 1.174 & 0.6394 & $(-3.834,6.182)$ \\
\hline Number of pp65pentamer+CD28- EM/ $\mu 1$ & 3.538 & 0.0014 & $(1.445,5.63)$ \\
\hline
\end{tabular}


selective increase of functional CD8 $+\mathrm{T}$ cells was significant between adults and early aged (65-85 years), but not between the latter category and oldest old subjects ( $>85$ years). Lastly, in another study conducted in subjects of different health condition across later life (Vescovini et al. 2010), we could not detect significant increase in memory inflation due to either age or to health. Therefore, although the notion that elderly maintain greater numbers of anti-CMV CD8+ T cells than young subjects is undisputable, current data suggest that later phases of life may not be necessarily accompanied by endless expansion of anti-CMV CD8+ T cells. This concept will need to be confirmed by longitudinal studies addressing the dynamic at the individual level throughout late age, however observation so far extended to a few years of follow-up have not reported significant alterations (Iancu et al. 2009; Miles et al. 2008; Wallace et al. 2011), even in subjects approaching the end of life (Hadrup et al. 2006).

Naïve CD8+ T cell homeostasis and its age-related deregulation are likely relevant for primary immune responses, for vaccination strategies and possibly for survival even in advanced age (Ferrando-Martinez et al. 2011, 2013). Results in this paper, showing no influence of anti-CMV reactivity on naive T cells, are apparently inconsistent with the current notion that CMV infection plays an active role in depleting the naive $\mathrm{T}$ cell pool. Indeed, several reports have documented that subjects with CMV retain significantly fewer naïve $\mathrm{T}$ cells than age-matched uninfected subjects, particularly when relative population representation is evaluated (Almanzar et al. 2005; Chidrawar et al. 2009; Derhovanessian et al. 2010, 2011; Litjens et al. 2011; Sauce et al. 2009), whereas primary CMV infection induces a sudden drop of the percentage of naïve T cells, regardless of age (van de Berg et al. 2010). Also, a recent report by Lachmann et al. (2012) showed that even size of pp65-specific CD8+ T cell response correlated significantly with a relative loss of naive T cells. It is uncertain whether this widely reported CMV-related depletion of CD8+ naive T cells may occur simply because of massive naïve $\mathrm{T}$ cell recruitment in primary infection, or rather because of other effects in chronic infection (Vezys et al. 2006). Synergistic detrimental effects by CMV chronic infection could consist in enhanced consumption of naïve $\mathrm{T}$ cells with reduced supply of novel naïve $\mathrm{T}$ cells by declining thymic function (Gress and Deeks 2009). Also, naïve T cells may have their "immunological space" usurped by expanded anti-
CMV CD8+ T cells. If any of these hypothetical plausible scenarios were in play, numbers of naïve $\mathrm{T}$ cells would be expected to inversely correlate with the size of anti-CMV responses. But we did not observe any significant correlation between size of anti-pp65 and antiIE-1 CD8+ T cells and CD8+ naive T cells (Fig. 3 and Tables 2 and 3), thus ruling out such a hypothesis. Likewise, another cross-sectional study of large numbers of $\mathrm{CMV}-$ and $\mathrm{CMV}+$ subjects (Wertheimer et al., submitted for publication) is confirming that persistent CMV infection neither engages significant numbers of naïve $\mathrm{T}$ cells, nor contributes to accelerate physiological age-related naïve $\mathrm{T}$ cell loss. Furthermore, two recent reports (Chidrawar et al. 2009; Litjens et al. 2011) have shown that differences in naïve $\mathrm{T}$ cells numbers between CMV-negative and CMV-positive subjects may be quite constant throughout adulthood and aging. So, when considering all previously published papers as well as current results, the overall likely hypothesis is that CMV-driven depletion of naive CD8+ T cells derives from recruitment of anti-CMV naïve CD8+ T cells into antigen-experienced CD8+ T cells during primary infection. Once most CMVspecific naïve $\mathrm{T}$ cells have been mobilized in the early phase of infection, remaining naïve CD8 $\mathrm{T}$ cells still circulating in elderly people are neutral to anti-CMV responses because they carry TCR specificities irrelevant to CMV antigens. Finally, regardless of CMV-driven CD8+ naive $\mathrm{T}$ depletion, one main aspect of these data is that the tiny immunological space occupied by naïve CD8+ T cells was not endangered by expanded antigenexperienced CD8+ T cells.

The expanded immunological space of antigenexperienced CD8 $+\mathrm{T}$ cells was still characterized by broad individual variability of CD8 + CD28- T cells (Figs. 1 and 2) although all subjects were selected as CMV-seropositive. Remarkably, variation of the CD8+ CD28- EM T cell subset strictly correlated with whole CD8+ T cells (Fig. 1c, e). Notably, we found that the size of the CD28-CD8+ T cell subset was predicted by CD8+ T cell reactivity to immunodominant epitopes of pp65 antigen. By contrast, none of the other variables considered in this study, including age, gender, health status, educational level (as an indirect socioeconomic status indicator) and anti-CMV IgG Ab level, revealed to be significant in this regard. These results confirm and extend the previous findings by Lachmann et al. (2012) in a smaller cohort showing that the degree of advanced $\mathrm{T}$ cell memory differentiation correlates with the actual size of CD4 and CD8 anti-pp65 T-cell responses. 
Moreover, we found that antigen-experienced CD8+ T cell numbers, including not only CD28- but also CD28+ CD8+ T cells, were significantly predicted by INF- $\gamma$ responses to overlapping peptides of entire pp65 and IE-1 proteins. In spite of differences between pMHC staining and ICS assay, results obtained by both methods were highly consistent and predicted size variability of memory/effector CD8+ T cells, thus strengthening our conclusions. It should be noted that these results are somewhat surprising when considering the limited extent of antigen-specificity to which they were tested, and should be considered preliminary for this reason. Nevertheless, after demonstration by several reports of common alterations in CD8 $+\mathrm{T}$ cell subsets conferred by CMV-seropositivity, this study illustrates that $\mathrm{CD} 8+\mathrm{T}$ cell reactivity to just two well-known immunodominant antigens (pp65 and IE-1) explains a significant degree of the individual variability of antigenexperienced, CD28-CD8+, and whole CD8+ T cells.

The origin of inter-individual variability of CD8+ T cell responses to pp65 and IE-1 remains unclear. Interestingly, it has been recently reported that subjects genetically enriched for longevity are less susceptible to the characteristic CMV-associated antigen-driven immune alterations commonly considered to be the hallmarks of immunosenescence (Derhovanessian et al. 2010). Other factors independent from genetic predisposition could also play roles, such as: length of time from primary infection, distinct CMV viral strains (Pignatelli et al. 2010), site of viral persistence (Leng et al. 2011), degree of thymic involution and naive T cell reservoir faced with primary infection (Pitcher et al. 2002; Sauce et al. 2009), different individual behaviours regarding physical exercise (Turner et al. 2010) and/or caloric intake (Messaoudi et al. 2006), prior events of lymphodepletion counteracted by $\mathrm{T}$ lymphocyte homeostatic mechanisms (Fagnoni et al. 2002). Regardless of origin(s) of individual variability, we have seen that CMV-driven CD8+ T cell reactivity is correlated with increasing numbers of late differentiated CD28-CD8+ T cells. This parameter make up a substantial part of the highly discussed Immune Risk Phenotype (IRP) considered for the potential prediction of increased morbidity and death (Wikby et al. 2002). As CMV-driven immunosenescence and IRP may be considered biomarkers of the emerging pathological role of CMV in accelerating senescence, findings from this study may help to design appropriate interventional therapeutic protocols in selected CMV-seropositive subjects to target CMV-sensitive endpoints still potentially reversible.

Acknowledgments We thank Dirce Gennari for her technical assistance and Paul Rizza for his editing support. This work was supported by grants from the Ministero dell'Istruzione, dell'Università e della Ricerca (PRIN2006, "La longevità dei genitori influenza l'invecchiamento in salute dei figli?") (P.S., D.M. and C.F.) and the Fondazione Cassa di Risparmio di Parma e Piacenza (P. S.).

Conflict of interest The authors of this manuscript have no conflict of interests to declare.

Open Access This article is distributed under the terms of the Creative Commons Attribution License which permits any use, distribution, and reproduction in any medium, provided the original author(s) and the source are credited.

\section{References}

Almanzar G, Schwaiger S, Jenewein B, Keller M, HerndlerBrandstetter D, Wurzner R, Schonitzer D, GrubeckLoebenstein B (2005) Long-term cytomegalovirus infection leads to significant changes in the composition of the CD8+ T-cell repertoire, which may be the basis for an imbalance in the cytokine production profile in elderly persons. J Virol 79(6):3675-3683. doi:10.1128/JVI.79.6.3675-3683.2005

Boeckh M, Geballe AP (2011) Cytomegalovirus: pathogen, paradigm, and puzzle. J Clin Invest 121(5):1673-1680. doi:10. 1172/JCI45449

Chidrawar S, Khan N, Wei W, McLarnon A, Smith N, Nayak L, Moss P (2009) Cytomegalovirus-seropositivity has a profound influence on the magnitude of major lymphoid subsets within healthy individuals. Clin Exp Immunol 155(3):423432. doi:10.1111/j.1365-2249.2008.03785.x

Cicin-Sain L, Sylwester AW, Hagen SI, Siess DC, Currier N, Legasse AW, Fischer MB, Koudelka CW, Axthelm MK, Nikolich-Zugich J, Picker LJ (2011) Cytomegalovirusspecific $\mathrm{T}$ cell immunity is maintained in immunosenescent rhesus macaques. J Immunol 187(4):1722-1732. doi:10. 4049/jimmunol.1100560

Demmler GJ (2006) Cytomegalovirus infection: back to the future or no more elephants? Clin Infect Dis 43(9):1152-1153. doi: 10.1086/508204

Derhovanessian E, Maier AB, Beck R, Jahn G, Hahnel K, Slagboom PE, de Craen AJ, Westendorp RG, Pawelec G (2010) Hallmark features of immunosenescence are absent in familial longevity. J Immunol 185(8):4618-4624. doi:10. 4049/jimmunol.1001629

Derhovanessian E, Maier AB, Hahnel K, Beck R, de Craen AJ, Slagboom EP, Westendorp RG, Pawelec G (2011) Infection with cytomegalovirus but not herpes simplex virus induces the accumulation of late-differentiated CD4+ and CD8+ Tcells in humans. J Gen Virol 92(Pt 12):2746-2756. doi:10. 1099/vir.0.036004-0

Fagnoni FF, Vescovini R, Mazzola M, Bologna G, Nigro E, Lavagetto G, Franceschi C, Passeri M, Sansoni P (1996) Expansion of cytotoxic CD8+ CD28- T cells in healthy 
ageing people, including centenarians. Immunology 88(4): 501-507

Fagnoni FF, Vescovini R, Passeri G, Bologna G, Pedrazzoni M, Lavagetto G, Casti A, Franceschi C, Passeri M, Sansoni P (2000) Shortage of circulating naive CD8(+) T cells provides new insights on immunodeficiency in aging. Blood 95(9): 2860-2868

Fagnoni FF, Lozza L, Zibera C, Zambelli A, Ponchio L, Gibelli N, Oliviero B, Pavesi L, Gennari R, Vescovini R, Sansoni P, Da Prada G, Robustelli Della Cuna G (2002) T-cell dynamics after high-dose chemotherapy in adults: elucidation of the elusive CD8+ subset reveals multiple homeostatic T-cell compartments with distinct implications for immune competence. Immunology 106(1):27-37

Ferrando-Martinez S, Ruiz-Mateos E, Hernandez A, Gutierrez E, Rodriguez-Mendez Mdel M, Ordonez A, Leal M (2011) Age-related deregulation of naive $\mathrm{T}$ cell homeostasis in elderly humans. Age (Dordr) 33(2):197-207. doi:10.1007/ s11357-010-9170-8

Ferrando-Martinez S, Romero-Sanchez MC, Solana R, Delgado J, de la Rosa R, Munoz-Fernandez MA, Ruiz-Mateos E, Leal M (2013) Thymic function failure and C-reactive protein levels are independent predictors of all-cause mortality in healthy elderly humans. Age (Dordr) 35(1):251-259. doi: 10.1007/s11357-011-9341-2

Gress RE, Deeks SG (2009) Reduced thymus activity and infection prematurely age the immune system. J Clin Invest 119(10):2884-2887. doi:10.1172/JCI40855

Hadrup SR, Strindhall J, Kollgaard T, Seremet T, Johansson B, Pawelec G, thor Straten P, Wikby A (2006) Longitudinal studies of clonally expanded CD8 T cells reveal a repertoire shrinkage predicting mortality and an increased number of dysfunctional cytomegalovirus-specific $\mathrm{T}$ cells in the very elderly. J Immunol 176(4):2645-2653

Iancu EM, Corthesy P, Baumgaertner P, Devevre E, Voelter V, Romero P, Speiser DE, Rufer N (2009) Clonotype selection and composition of human CD8 T cells specific for persistent herpes viruses varies with differentiation but is stable over time. J Immunol 183(1):319-331. doi:10.4049/jimmunol. 0803647

Kern F, Faulhaber N, Frommel C, Khatamzas E, Prosch S, Schonemann C, Kretzschmar I, Volkmer-Engert R, Volk HD, Reinke P (2000) Analysis of CD8 T cell reactivity to cytomegalovirus using proteinspanning pools of overlapping pentadecapeptides. Eur J Immunol 30(6):1676-1682. doi:10.1002/1521-4141(200006) 30:6<1676::AID-IMMU1676>3.0.CO;2-V

Khan N, Shariff N, Cobbold M, Bruton R, Ainsworth JA, Sinclair AJ, Nayak L, Moss PA (2002) Cytomegalovirus seropositivity drives the CD8 T cell repertoire toward greater clonality in healthy elderly individuals. J Immunol 169(4):1984-1992

Khan N, Hislop A, Gudgeon N, Cobbold M, Khanna R, Nayak L, Rickinson AB, Moss PA (2004) Herpesvirus-specific CD8 T cell immunity in old age: cytomegalovirus impairs the response to a coresident EBV infection. J Immunol 173(12):7481-7489

Khan N, Best D, Bruton R, Nayak L, Rickinson AB, Moss PA (2007) T cell recognition patterns of immunodominant cytomegalovirus antigens in primary and persistent infection. $\mathrm{J}$ Immunol 178(7):4455-4465

Koch S, Larbi A, Ozcelik D, Solana R, Gouttefangeas C, Attig S, Wikby A, Strindhall J, Franceschi C, Pawelec G (2007) Cytomegalovirus infection: a driving force in human $\mathrm{T}$ cell immunosenescence. Ann N Y Acad Sci 1114:23-35. doi:10. 1196/annals.1396.043

Lachmann R, Bajwa M, Vita S, Smith H, Cheek E, Akbar A, Kern F (2012) Polyfunctional T cells accumulate in large human cytomegalovirus-specific T cell responses. J Virol 86(2): 1001-1009

Lang A, Nikolich-Zugich J (2011) Functional CD8 T cell memory responding to persistent latent infection is maintained for life. $\mathrm{J}$ Immunol 187(7):3759-3768. doi:10.4049/jimmunol.1100666

Lang A, Brien JD, Nikolich-Zugich J (2009) Inflation and longterm maintenance of $\mathrm{CD} 8 \mathrm{~T}$ cells responding to a latent herpesvirus depend upon establishment of latency and presence of viral antigens. J Immunol 183(12):8077-8087. doi: 10.4049/jimmunol.0801117

Leng SX, Qu T, Semba RD, Li H, Yao X, Nilles T, Yang X, Manwani B, Walston JD, Ferrucci L, Fried LP, Margolick JB, Bream JH (2011) Relationship between cytomegalovirus (CMV) IgG serology, detectable CMV DNA in peripheral monocytes, and CMV pp 65(495-503)-specific CD8+ T cells in older adults. Age (Dordr) 33(4):607-614. doi:10.1007/s11357-0119205-9

Litjens NH, de Wit EA, Betjes MG (2011) Differential effects of age, cytomegalovirus-seropositivity and end-stage renal disease (ESRD) on circulating $\mathrm{T}$ lymphocyte subsets. Immun Ageing 8(1):2. doi:10.1186/1742-4933-8-2

Looney RJ, Falsey A, Campbell D, Torres A, Kolassa J, Brower C, McCann R, Menegus M, McCormick K, Frampton M, Hall W, Abraham GN (1999) Role of cytomegalovirus in the T cell changes seen in elderly individuals. Clin Immunol 90(2): 213-219. doi:10.1006/clim.1998.4638

McElhaney JE, Effros RB (2009) Immunosenescence: what does it mean to health outcomes in older adults? Curr Opin Immunol 21(4):418-424. doi:10.1016/j.coi.2009.05.023

Messaoudi I, Warner J, Fischer M, Park B, Hill B, Mattison J, Lane MA, Roth GS, Ingram DK, Picker LJ, Douek DC, Mori M, Nikolich-Zugich J (2006) Delay of T cell senescence by caloric restriction in aged long-lived nonhuman primates. Proc Natl Acad Sci U S A 103(51):19448-19453. doi:10. 1073/pnas.0606661103

Miles DJ, van der Sande M, Jeffries D, Kaye S, Ojuola O, Sanneh M, Cox M, Palmero MS, Touray ES, Waight P, RowlandJones S, Whittle H, Marchant A (2008) Maintenance of large subpopulations of differentiated CD8 T-cells two years after cytomegalovirus infection in Gambian infants. PLoS One 3(8):e2905. doi:10.1371/journal.pone.0002905

Moss P (2010) The emerging role of cytomegalovirus in driving immune senescence: a novel therapeutic opportunity for improving health in the elderly. Curr Opin Immunol 22(4):529534. doi:10.1016/j.coi.2010.07.001

Natali A, Valcavi P, Medici MC, Dieci E, Montali S, Chezzi C (1997) Cytomegalovirus infection in an Italian population: antibody prevalence, virus excretion and maternal transmission. New Microbiol 20(2):123-133

Ouyang Q, Wagner WM, Zheng W, Wikby A, Remarque EJ, Pawelec G (2004) Dysfunctional CMV-specific CD8(+) T cells accumulate in the elderly. Exp Gerontol 39(4):607-613. doi:10.1016/j.exger.2003.11.016

Pawelec G (2006) Immunity and ageing in man. Exp Gerontol 41(12):1239-1242. doi:10.1016/j.exger.2006.09.005

Pawelec G, Koch S, Franceschi C, Wikby A (2006) Human immunosenescence: does it have an infectious component? 
Ann N Y Acad Sci 1067:56-65. doi:10.1196/annals.1354. 009

Pawelec G, Akbar A, Beverley P, Caruso C, Derhovanessian E, Fulop T, Griffiths P, Grubeck-Loebenstein B, Hamprecht K, Jahn G, Kern F, Koch SD, Larbi A, Maier AB, Macallan D, Moss P, Samson S, Strindhall J, Trannoy E, Wills M (2010) Immunosenescence and Cytomegalovirus: where do we stand after a decade? Immun Ageing 7:13. doi:10.1186/ 1742-4933-7-13

Pignatelli S, Lazzarotto T, Gatto MR, Dal Monte P, Landini MP, Faldella G, Lanari M (2010) Cytomegalovirus gN genotypes distribution among congenitally infected newborns and their relationship with symptoms at birth and sequelae. Clin Infect Dis 51(1):33-41. doi:10.1086/653423

Pita-Lopez ML, Gayoso I, DelaRosa O, Casado JG, Alonso C, Munoz-Gomariz E, Tarazona R, Solana R (2009) Effect of ageing on CMV-specific CD8 T cells from CMV seropositive healthy donors. Immun Ageing 6:11. doi:10.1186/1742-4933-6-11

Pitcher CJ, Hagen SI, Walker JM, Lum R, Mitchell BL, Maino VC, Axthelm MK, Picker LJ (2002) Development and homeostasis of T cell memory in rhesus macaque. J Immunol 168(1):29-43

Sauce D, Larsen M, Fastenackels S, Duperrier A, Keller M, Grubeck-Loebenstein B, Ferrand C, Debre P, Sidi D, Appay V (2009) Evidence of premature immune aging in patients thymectomized during early childhood. J Clin Invest 119(10):3070-3078. doi:10.1172/JCI39269

Snyder CM, Cho KS, Bonnett EL, van Dommelen S, Shellam GR, Hill AB (2008) Memory inflation during chronic viral infection is maintained by continuous production of short-lived, functional T cells. Immunity 29(4):650-659. doi:10.1016/j. immuni.2008.07.017

Sylwester AW, Mitchell BL, Edgar JB, Taormina C, Pelte C, Ruchti F, Sleath PR, Grabstein KH, Hosken NA, Kern F, Nelson JA, Picker LJ (2005) Broadly targeted human cytomegalovirus-specific CD4+ and CD8+ T cells dominate the memory compartments of exposed subjects. J Exp Med 202(5):673-685. doi:10.1084/jem.20050882

Turner JE, Aldred S, Witard OC, Drayson MT, Moss PM, Bosch JA (2010) Latent cytomegalovirus infection amplifies CD8 T-lymphocyte mobilisation and egress in response to exercise. Brain Behav Immun 24(8):1362-1370. doi:10.1016/j. bbi.2010.07.239

van de Berg PJ, van Stijn A, Ten Berge IJ, van Lier RA (2008) A fingerprint left by cytomegalovirus infection in the human $\mathrm{T}$ cell compartment. J Clin Virol 41(3):213-217. doi:10.1016/j. jcv.2007.10.016

van de Berg PJ, Griffiths SJ, Yong SL, Macaulay R, Bemelman FJ, Jackson S, Henson SM, ten Berge IJ, Akbar AN, van Lier RA
(2010) Cytomegalovirus infection reduces telomere length of the circulating T cell pool. J Immunol 184(7):3417-3423. doi:10.4049/jimmunol.0903442

Vescovini R, Telera A, Fagnoni FF, Biasini C, Medici MC, Valcavi P, di Pede P, Lucchini G, Zanlari L, Passeri G, Zanni F, Chezzi C, Franceschi C, Sansoni P (2004) Different contribution of EBV and CMV infections in very long-term carriers to age-related alterations of CD8+ T cells. Exp Gerontol 39(8):1233-1243. doi:10.1016/j.exger.2004.04.004

Vescovini R, Biasini C, Fagnoni FF, Telera AR, Zanlari L, Pedrazzoni M, Bucci L, Monti D, Medici MC, Chezzi C, Franceschi C, Sansoni P (2007) Massive load of functional effector CD4+ and CD8+ T cells against cytomegalovirus in very old subjects. J Immunol 179(6):4283-4291

Vescovini R, Biasini C, Telera AR, Basaglia M, Stella A, Magalini F, Bucci L, Monti D, Lazzarotto T, Dal Monte P, Pedrazzoni M, Medici MC, Chezzi C, Franceschi C, Fagnoni FF, Sansoni P (2010) Intense antiextracellular adaptive immune response to human cytomegalovirus in very old subjects with impaired health and cognitive and functional status. J Immunol 184(6):3242-3249. doi:10.4049/jimmunol. 0902890

Vezys V, Masopust D, Kemball CC, Barber DL, O'Mara LA, Larsen CP, Pearson TC, Ahmed R, Lukacher AE (2006) Continuous recruitment of naive $\mathrm{T}$ cells contributes to heterogeneity of antiviral CD8 T cells during persistent infection. J Exp Med 203(10):2263-2269. doi:10.1084/jem. 20060995

Wallace DL, Masters JE, De Lara CM, Henson SM, Worth A, Zhang Y, Kumar SR, Beverley PC, Akbar AN, Macallan DC (2011) Human cytomegalovirus-specific CD8(+) T-cell expansions contain long-lived cells that retain functional capacity in both young and elderly subjects. Immunology 132(1): 27-38. doi:10.1111/j.1365-2567.2010.03334.x

Weinberger B, Lazuardi L, Weiskirchner I, Keller M, Neuner C, Fischer KH, Neuman B, Wurzner R, Grubeck-Loebenstein B (2007) Healthy aging and latent infection with CMV lead to distinct changes in CD8+ and CD4+ T-cell subsets in the elderly. Hum Immunol 68(2):86-90. doi:10.1016/j.humimm. 2006.10.019

Weng NP, Akbar AN, Goronzy J (2009) CD28(-) T cells: their role in the age-associated decline of immune function. Trends Immunol 30(7):306-312. doi:10.1016/j.it.2009.03.013

Wikby A, Johansson B, Olsson J, Lofgren S, Nilsson BO, Ferguson F (2002) Expansions of peripheral blood CD8 Tlymphocyte subpopulations and an association with cytomegalovirus seropositivity in the elderly: the Swedish NONA immune study. Exp Gerontol 37(2-3):445-453 